\title{
Pancreatic lymphoepithelial cysts express CEA and can contain mucous cells: potential pitfalls in the preoperative diagnosis
}

Jay S Raval ${ }^{1}$, Herbert J Zeh², A James Moser ${ }^{2}$, Kenneth K Lee ${ }^{2}$, Michael K Sanders ${ }^{3}$, Sarah Navina ${ }^{1}$, Shih-Fan Kuan ${ }^{1}$ and Alyssa M Krasinskas ${ }^{1}$

${ }^{1}$ Department of Pathology, University of Pittsburgh Medical Center, Pittsburgh, PA, USA; ${ }^{2}$ Department of Surgery, University of Pittsburgh Medical Center, Pittsburgh, PA, USA and ${ }^{3}$ Department of Medicine, University of Pittsburgh Medical Center, Pittsburgh, PA, USA

Pancreatic lymphoepithelial cysts are rare benign cysts that cannot be reliably differentiated from neoplastic mucinous cysts preoperatively. Although elevated cyst fluid carcinoembryonic antigen (CEA) levels support a diagnosis of a mucinous cyst, the finding of increased CEA levels in lymphoepithelial cysts prompted this study. Nine resected lymphoepithelial cysts were examined for expression of CEA, carbohydrate antigen (CA) 19-9, CK7, p63, PAS-D and a panel of mucins. The pathology data were correlated with clinical information, including serum, cyst fluid and imaging studies. By computed tomography scan, although most lymphoepithelial cysts appeared cystic, $23 \%$ were described as masses. The endoscopic ultrasound findings were variable, but the lymphoepithelial cysts tended to be hypoechoic cystic lesions or masses. On cytology, $44 \%$ of the cysts had squamous cells, $67 \%$ had glandular cells and $56 \%$ had atypical cells. The cysts were resected because of size $\geq 3 \mathrm{~cm}(89 \%)$, symptoms (44\%) and/or elevated cyst fluid CEA levels (33\%). The cyst fluid CEA levels in the three cysts tested were $>450 \mathrm{ng} / \mathrm{ml}$. Histopathologically, all cysts were lined by mature, stratified squamous-type cells and produced keratin. Mucous cells were present in $78 \%$ of the cysts. The immunohistochemical profile of the squamous lining was CK7+, p63 +, MUC1+, MUC4 +, MUC2-, MUC5AC- and MUC6-. Even though lymphoepithelial cysts are lined by squamous-type epithelium, all our resected lymphoepithelial cysts expressed CEA and/or CA19-9, many contained mucous cells, and three exhibited markedly elevated cyst fluid CEA levels. Although cyst fluid CEA levels $>200 \mathrm{ng} / \mathrm{ml}$ support the diagnosis of mucinous neoplasms, this study emphasizes the need for clinicians and pathologists to recognize that lymphoepithelial cysts can mimic neoplastic mucinous cysts clinically, radiographically and on cyst fluid CEA analysis.

Modern Pathology (2010) 23, 1467-1476; doi:10.1038/modpathol.2010.144; published online 27 August 2010

Keywords: carcinoembryonic antigen; endoscopic ultrasound; fine needle aspiration; lymphoepithelial cyst; pancreatic mucinous cyst

Pancreatic lymphoepithelial cysts are rare, benign cysts that are typically lined by mature, keratinizing squamous epithelium with surrounding lymphoid tissue. These cysts tend to occur in middle- to olderaged men (male/female ratio 4:1 with a mean age of 56 years). ${ }^{1}$ Lymphoepithelial cysts can be unilocular

Correspondence: Dr AM Krasinskas, MD, Department of Pathology, University of Pittsburgh Medical Center, Presbyterian Hospital, A610, 200 Lothrop Street, Pittsburgh, PA 15213-2546, USA.

E-mail: krasinskasam@upmc.edu

Received 30 March 2010; revised 28 May 2010; accepted 31 May 2010; published online 27 August 2010 or multilocular, can occur throughout the pancreas and often protrude outside the pancreas. The mean size of resected lymphoepithelial cyst cysts is $4.7 \mathrm{~cm}$, but cysts up to $17 \mathrm{~cm}$ in size have been reported. ${ }^{2}$ Although easy to diagnose on a resection specimen, any cysts in the pancreas, including lymphoepithelial cysts, can pose diagnostic challenges preoperatively.

Most lymphoepithelial cysts are found incidentally on imaging studies performed for unrelated reasons. When characteristic features are present, computerized tomography (CT) and magnetic resonance imaging (MRI) can help support the diagnosis of lymphoepithelial cyst. However, imaging studies 
cannot consistently separate lymphoepithelial cysts from neoplastic mucinous cysts, such as mucinous cystic neoplasms and intraductal papillary mucinous neoplasms. Fine needle aspiration (FNA) can also support the diagnosis of a lymphoepithelial cyst when squamous cells or keratinous material is present, but FNA can yield inconclusive results, especially if atypical glandular cells are present.

Cyst fluid analysis can be a helpful tool in distinguishing neoplastic (mucinous) from nonneoplastic (nonmucinous) cysts. Several markers, such as carcinoembryonic antigen (CEA), cancer antigen 72-4, carbohydrate antigen (CA) 19-9, fluid viscosity, amylase and lipase, have been extensively studied. Currently, measurement of cyst fluid CEA appears to be the most useful marker to discriminate between mucinous and nonmucinous cysts. ${ }^{3}$ In a recently proposed algorithm for the diagnosis of pancreatic cysts, if a cystic neoplasm is suspected on endoscopic ultrasound and there is no solid component, a cyst fluid CEA level $>200 \mathrm{ng} / \mathrm{ml}$ supports the diagnosis of a mucinous neoplasm. ${ }^{3}$

Using cyst fluid CEA as a discriminating test has its limitations, including known false-positive results. Several case reports have noted elevated levels of both CEA and CA19-9 in lymphoepithelial cysts. ${ }^{4-9}$ This is an important diagnostic pitfall in lymphoepithelial cysts that needs to be further addressed, as patients who have any suspicion of harboring a neoplastic cyst often have the cyst resected. In this study, we reviewed a series of nine lymphoepithelial cysts that were resected at our institution. We correlated the preoperative imaging findings, FNA cytology results and cyst fluid analysis with the postoperative histopathological findings. We also further investigated the potential cause for elevated CEA and CA19-9 in lymphoepithelial cysts.

\section{Materials and methods}

We searched the University of Pittsburgh Medical Center Department of Pathology surgical pathology files for patients with a final diagnosis of lymphoepithelial cyst from 2002 to 2009 . This query yielded nine resected lymphoepithelial cysts. The gross descriptions of the lesions were reviewed, along with demographic information about the patients including sex and age. Corresponding cytology diagnoses were reviewed, as were serum and cyst fluid CEA and CA19-9 levels if obtained before resection.

The histology of all eight cases was reviewed and a representative formalin-fixed paraffin-embedded tissue block from each case was selected and serially sectioned. One section of each block was stained with hematoxylin and eosin. The remaining serial sections were stained with PAS-D, CEA, CA19-9, CK7, p63 and the mucins MUC1, MUC2, MUC4, MUC5AC and MUC6 (see Supplementary Table 1 for antibody clones and dilutions). Standard automated immunohistochemistry was performed using the Ventana BenchMark XT system for CEA, CA19-9, CK7 and p63. Standard manual immunohistochemistry was performed for the mucins according to the vendor's instructions and previously published methods. ${ }^{10}$ All histochemical and immunohistochemical stained sections were reviewed and the expression profiles of the lining of the cysts were recorded.

\section{Results}

The clinical data are summarized in Table 1. Six of the patients $(67 \%)$ were male and the mean age was 58 (range $40-75)$ years. Five (56\%) of the patients were symptomatic; three patients presented with abdominal pain and/or nausea, one patient presented with weight loss, and one patient with a concomitant pancreatic cancer presented with jaundice. In the remaining four patients, the cysts were found incidentally. Serum CEA and CA19-9 levels were measured preoperatively in six and five patients, respectively. In one patient (without cancer), the serum CEA level was elevated to $6.4 \mathrm{ng} / \mathrm{ml}$ (mean $2.7 \mathrm{ng} / \mathrm{ml}$, range $1-6.4 \mathrm{ng} / \mathrm{ml}$ ). Serum CA19-9 levels were elevated in three cases (mean $123.8 \mathrm{U} / \mathrm{ml}$, range $4-509 \mathrm{U} / \mathrm{ml})$. Of note, the patient with pancreatic cancer also had an elevated CA19-9 level, but his level was excluded from the analysis.

The location and macroscopic descriptions of the cysts are shown in Table 2. Most of the lymphoepithelial cysts were located in the neck/body (56\%), with the remainder in the head $(22 \%)$ and tail $(22 \%)$. Four $(44 \%)$ of the cysts were exophytic or appeared to be within the peripancreatic soft tissue. Eight (89\%) of the cysts were $\geq 3 \mathrm{~cm}$ with a mean cyst size of $4.4 \mathrm{~cm}$ and range of $2.5-10 \mathrm{~cm}$. Five were multilocular (56\%) and four were unilocular (44\%). One patient with a lymphoepithelial cyst in the body (LEC2) had pancreatic ductal adenocarcinoma in the head.

Eight patients had both CT and endoscopic ultrasound imaging studies performed; one patient only had a CT scan. The results and impression

Table 1 Clinical information

\begin{tabular}{lcclcc}
\hline & Sex & $\begin{array}{c}\text { Age } \\
\text { (years) }\end{array}$ & Presentation & $\begin{array}{c}\text { Serum } \\
\text { CEA } \\
\text { (ng/ml) }\end{array}$ & $\begin{array}{c}\text { Serum } \\
\text { CA19-9 } \\
\text { (U/ml) }\end{array}$ \\
& & & & \\
\hline LEC1 & $\mathrm{M}$ & 58 & Weight loss & 2.5 & 51.9 \\
LEC2 & $\mathrm{M}$ & 58 & Jaundice & 1.2 & $\mathrm{~N} / \mathrm{A}$ \\
LEC3 & $\mathrm{M}$ & 75 & New right upper & $\mathrm{N} / \mathrm{A}$ & 188 \\
& & & abdominal pain & & \\
LEC4 & $\mathrm{F}$ & 41 & Epigastric pain & $\mathrm{N} / \mathrm{A}$ & $\mathrm{N} / \mathrm{A}$ \\
LEC5 & $\mathrm{F}$ & 40 & Epigastric pain, nausea & 3.7 & 13.9 \\
LEC6 & $\mathrm{M}$ & 75 & Incidental & 1 & 4 \\
LEC7 & $\mathrm{F}$ & 59 & Incidental & 1.3 & $\mathrm{~N} / \mathrm{A}$ \\
LEC8 & $\mathrm{M}$ & 66 & Found 8 years prior & 6.4 & 509 \\
LEC9 & $\mathrm{M}$ & 50 & Found 2 years prior & $\mathrm{N} / \mathrm{A}$ & $\mathrm{N} / \mathrm{A}$ \\
& & & & \\
\hline
\end{tabular}

LEC, lymphoepithelial cyst; N/A, not available. 
Table 2 Description of the lymphoepithelial cysts

\begin{tabular}{llcllll}
\hline & Cyst location & $\begin{array}{c}\text { Cyst size } \\
\text { (cm) }\end{array}$ & Multilocular & $\begin{array}{l}\text { FNA fluid } \\
\text { description }\end{array}$ & Cyst contents on gross \\
CEA (ng/ml)
\end{tabular}

LEC, lymphoepithelial cyst; N/A, not available.

${ }^{\mathrm{a}}$ Initial analysis revealed a normal cyst fluid CEA level; a study repeated 8 months later revealed an elevated CEA level.

${ }^{b}$ Obtained at an outside institution.

Table 3 Imaging findings

\begin{tabular}{|c|c|c|c|c|}
\hline & CT findings & CT impression & Endoscopic ultrasound findings & $\begin{array}{l}\text { Endoscopic } \\
\text { ultrasound impression }\end{array}$ \\
\hline LEC1 & $\begin{array}{l}\text { Large cystic lesion in the } \\
\text { tail with mural nodularity }\end{array}$ & Not given & $\begin{array}{l}\text { Hypoechoic, heterogeneous mass with } \\
\text { thin wall extrinsic to the pancreas near } \\
\text { neck/body }\end{array}$ & $\begin{array}{l}\text { Lymphoepithelial cyst, } \\
\text { pseudocyst, } \\
\text { mesenteric cyst, other }\end{array}$ \\
\hline LEC2 & $\begin{array}{l}\text { Multicystic lesion } \\
\text { superior to the body }\end{array}$ & Not given & $\begin{array}{l}\text { Hypoechoic and heterogeneous mass in } \\
\text { body of pancreas with adjacent cystic } \\
\text { structures }\end{array}$ & Not given \\
\hline LEC3 & $\begin{array}{l}\text { Complex cystic mass } \\
\text { within the head }\end{array}$ & $\begin{array}{l}\text { Favor a cystic } \\
\text { neoplasm }\end{array}$ & $\begin{array}{l}\text { Hypoechoic and heterogeneous lesion in } \\
\text { the portacaval region }\end{array}$ & $\begin{array}{l}\text { Unclear relationship } \\
\text { to the pancreas }\end{array}$ \\
\hline LEC4 & $\begin{array}{l}\text { Hypodense mass near } \\
\text { superior aspect of the } \\
\text { neck }\end{array}$ & $\begin{array}{l}\text { Serous cyst, mucinous } \\
\text { cyst or exophytic } \\
\text { carcinoma }\end{array}$ & $\begin{array}{l}\text { Anechoic, distally enhancing lesion } \\
\text { (suggestive of a cyst) with thin outer wall } \\
\text { and a few thickly septated compartments; } \\
\text { one contains an intrinsic mass }\end{array}$ & $\begin{array}{l}\text { Possible oligocystic } \\
\text { serous cystadenoma or } \\
\text { mucinous cyst }\end{array}$ \\
\hline LEC5 & $\begin{array}{l}\text { Multicystic low-density } \\
\text { lesion within the head }\end{array}$ & $\begin{array}{l}\text { Could be a benign or } \\
\text { malignant neoplasm }\end{array}$ & $\begin{array}{l}\text { Oval hypoechoic and homogenous mass } \\
\text { with well-defined borders projecting from } \\
\text { or adjacent to the pancreatic body }\end{array}$ & $\begin{array}{l}\text { Duplication cyst, } \\
\text { pseudocyst or } \\
\text { endocrine neoplasm }\end{array}$ \\
\hline LEC6 & $\begin{array}{l}\text { Complex exophytic cystic } \\
\text { mass }\end{array}$ & Not given & $\begin{array}{l}\text { Complex exophytic mass budding off the } \\
\text { pancreas; more solid than cystic with } \\
\text { hypoechoic/anechoic areas }\end{array}$ & $\begin{array}{l}\text { Highly suspicious of a } \\
\text { neoplasm }\end{array}$ \\
\hline LEC7 & Complex cyst & Not given & $\begin{array}{l}\text { Very large, round mass replacing much of } \\
\text { the head of the pancreas with mixed } \\
\text { echogenicity }\end{array}$ & Not given \\
\hline LEC8 & $\begin{array}{l}\text { Large hypovascular mass } \\
\text { superior to the head }\end{array}$ & $\begin{array}{l}\text { Most likely a lymph } \\
\text { node mass }\end{array}$ & Not done (CT-guided FNA was performed) & Not given \\
\hline LEC9 & $\begin{array}{l}\text { Exophytic water density } \\
\text { cystic lesion off the tail }\end{array}$ & $\begin{array}{l}\text { Mucinous cystic } \\
\text { neoplasm; intraductal } \\
\text { papillary mucinous } \\
\text { neoplasm }\end{array}$ & $\begin{array}{l}\text { Single fluid-filled lesion within pancreas } \\
\text { with internal debris }\end{array}$ & $\begin{array}{l}\text { Intraductal papillary } \\
\text { mucinous neoplasm, } \\
\text { pseudocyst }\end{array}$ \\
\hline
\end{tabular}

LEC, lymphoepithelial cyst; CT, computerized tomography; FNA, fine needle aspiration.

of the imaging studies are summarized in Table 3. By CT, seven $(78 \%)$ of the lymphoepithelial cysts were described as cystic lesions, but two were described as noncystic masses. The endoscopic ultrasound findings were variable. The lymphoepithelial cysts appeared hypoechoic and heterogeneous $(n=3)$, hypoechoic and homogeneous $(n=1)$, anechoic with an intrinsic mass $(n=1)$, as complex masses with mixed echogenicity $(n=2)$ and as a single fluid-filled lesion with internal debris $(n=1)$.

All of the nine cases had FNA cytology performed. The descriptions of the cyst fluid are listed in Table 2 and the FNA cytology results are summarized in Table 4. On cytological examination, four cases (44\%) had squamous cells (Figure 1a) or squamous debris (Figure 1b), five (56\%) had macrophages (Figure 1a) or histiocytes, three (33\%) had acellular (nonkeratin) debris, and one case (11\%) had lymphocytes. Of note, six cysts $(67 \%)$ had glandular cells and five $(56 \%)$ had atypical cells present (Figure 1c). Only three patients had cyst fluid analysis for CEA (see Table 2), and in all three cysts, the CEA level was markedly elevated (to $493 \mathrm{ng} / \mathrm{ml}, 1091 \mathrm{ng} / \mathrm{ml}$ and $>100000 \mathrm{ng} / \mathrm{ml}$ ). The indications for surgery are 
Table 4 FNA cytology results, impression and reason for surgery

\begin{tabular}{|c|c|c|c|}
\hline & FNA cytology results & Cytological impression & Reason for surgery \\
\hline LEC1 & $\begin{array}{l}\text { Atypical cells present. Nucleated and } \\
\text { anucleated squamous epithelial cells and } \\
\text { degenerated debris present }\end{array}$ & $\begin{array}{l}\text { Benign cyst with squamous } \\
\text { features favored; malignancy } \\
\text { cannot be entirely excluded }\end{array}$ & Cyst size $>3 \mathrm{~cm}$; symptomatic \\
\hline LEC2 & $\begin{array}{l}\text { Atypical cells present; abundant squamous } \\
\text { debris, clusters of pancreatic acinar cells and } \\
\text { rare atypical glandular epithelial cells }\end{array}$ & $\begin{array}{l}\text { No definite evidence of } \\
\text { malignancy }\end{array}$ & $\begin{array}{l}\text { Cyst size }>3 \mathrm{~cm} \text {; removed during resection for } \\
\text { known cancer }\end{array}$ \\
\hline LEC3 & $\begin{array}{l}\text { Atypical cells present; hypocellular specimen } \\
\text { with atypical glandular epithelial cells; } \\
\text { possibly cyst contents }\end{array}$ & $\begin{array}{l}\text { LEC, abscess and possibly a } \\
\text { mucinous cyst; uncertain } \\
\text { malignant potential }\end{array}$ & Cyst size $\geq 3 \mathrm{~cm}$; symptomatic \\
\hline LEC4 & $\begin{array}{l}\text { Initial FNA: lymphocytes, few macrophages, } \\
\text { debris and bland epithelial cells; no squames. } \\
\text { Repeat FNA } 11 \text { months later: bland glandular } \\
\text { cells, histiocytes with rare multinucelated } \\
\text { histiocytes, debris and small lymphocytes }\end{array}$ & $\begin{array}{l}\text { Initial FNA: not a mucinous } \\
\text { cyst. Repeat FNA: epithelial } \\
\text { cells may represent cyst } \\
\text { lining; no high-grade } \\
\text { dysplasia }\end{array}$ & $\begin{array}{l}\text { Cyst size }>3 \mathrm{~cm} \text {; symptomatic; cyst fluid CEA } \\
>200 \mathrm{ng} / \mathrm{ml}\end{array}$ \\
\hline LEC5 & $\begin{array}{l}\text { Initial FNA: abundant debris including } \\
\text { anucleate squames, bland glandular cells, } \\
\text { stromal cells. Repeat FNA } 3 \text { months later: } \\
\text { mostly anucleate squames and few } \\
\text { macrophages }\end{array}$ & Squamous cyst & Cyst size $\geq 3 \mathrm{~cm}$; symptomatic \\
\hline LEC6 & $\begin{array}{l}\text { Abundant acellular debris, bland epithelium } \\
\text { and one cluster of atypical epithelium; no } \\
\text { squames }\end{array}$ & Not given & $\begin{array}{l}\text { Cyst size } \geq 3 \mathrm{~cm} \text {; solid component on } \\
\text { endoscopic ultrasound }\end{array}$ \\
\hline LEC7 & Sheets of epithelium, one focus of squames & Likely GI contaminant & Cyst size $>3 \mathrm{~cm}$ \\
\hline LEC8 & $\begin{array}{l}\text { Histiocytes and proteinaceous material } \\
\text { (outside hospital) }\end{array}$ & LEC & Cyst size $>3 \mathrm{~cm}$; cyst fluid CEA $>200 \mathrm{ng} / \mathrm{ml}$ \\
\hline LEC9 & Atypical glandular cells and macrophages & Cyst contents & Cyst fluid CEA > $200 \mathrm{ng} / \mathrm{ml}$ \\
\hline
\end{tabular}

LEC, lymphoepithelial cyst; FNA, fine needle aspiration.

also listed in Table 4 . Eight (89\%) of the cysts were removed because they exceeded $3 \mathrm{~cm}$ in diameter and/or were symptomatic and one cyst $(2.5 \mathrm{~cm})$ was removed because of concern for a mucinous cystic neoplasm with cyst fluid CEA $>600 \mathrm{ng} / \mathrm{ml}$.

The histological features of the lymphoepithelial cysts are shown in Figure 2. All resected cysts were lined, at least focally, by mature, stratified squamous cells; three cysts were predominantly denuded. Keratin was also present, at least focally, in all of the cysts. Beneath the squamous lining, eight cysts $(89 \%)$ had the characteristic dense lymphoid tissue with scattered germinal centers; one cyst had a markedly fibrotic wall with scattered lymphoid follicles. In six cases $(67 \%)$, there were focal-todiffuse areas where the cyst lining resembled transitional epithelium with a layer of plump cells without keratohyaline granules at the surface. Four $(44 \%)$ of the cysts had scattered sebaceous glands. Of particular interest was the presence of gobletshaped mucous cells within the superficial layer of the cyst lining in seven (78\%) of the cysts; the only cysts that did not contain these mucous cells were two of the cysts that were predominantly denuded and this could represent a false-negative finding. These mucous cells were rare (one to two individual cells or small clusters of cells) in three cysts, scattered ( $>2$ foci of cells present in $<30 \%$ of the cyst lining) in three cysts, and diffuse (scattered cells present in over $30 \%$ of the cyst lining) in one cyst. These mucous cells stained strongly for PAS after diastase (see Figure 3).

The results of the special stains, including the mucin expression profiles, are summarized in Supplementary Table 2 and representative photomicrographs are shown in Figure 3. CK7 (normally expressed in simple epithelium, including ductal epithelium and urothelium) and p63 (normally expressed in squamous epithelium and urothelium) were expressed in the squamous lining of all nine cysts (100\%); CK7 tended to label the surface, whereas p63 labeled the basal cells. Interestingly, all nine $(100 \%)$ cysts expressed either CEA or CA19-9 (patchy to diffuse staining) in the surface squamous cells; CEA and CA19-9 were both expressed in seven $(78 \%)$ cases. One of the two predominately denuded cysts did not show convincing expression of CEA, but was positive for CA19-9, whereas the other predominantly denuded cyst expressed CEA but not CA19-9. The mucous cells were variably positive for CEA and CA19-9 (see Figure 3 ). With regard to the mucins, primarily surface labeling of squamous cells was seen with MUC1 and MUC4 (100\%); MUC2 and MUC6 were negative in all nine cysts. MUC5AC labeled the mucous cells, so it was positive in seven $(78 \%)$ of the cases; in two cases, the MUC5AC labeling was very focal. The mucous cells also expressed MUC4, but they were negative for MUC1, MUC2 and MUC6. 

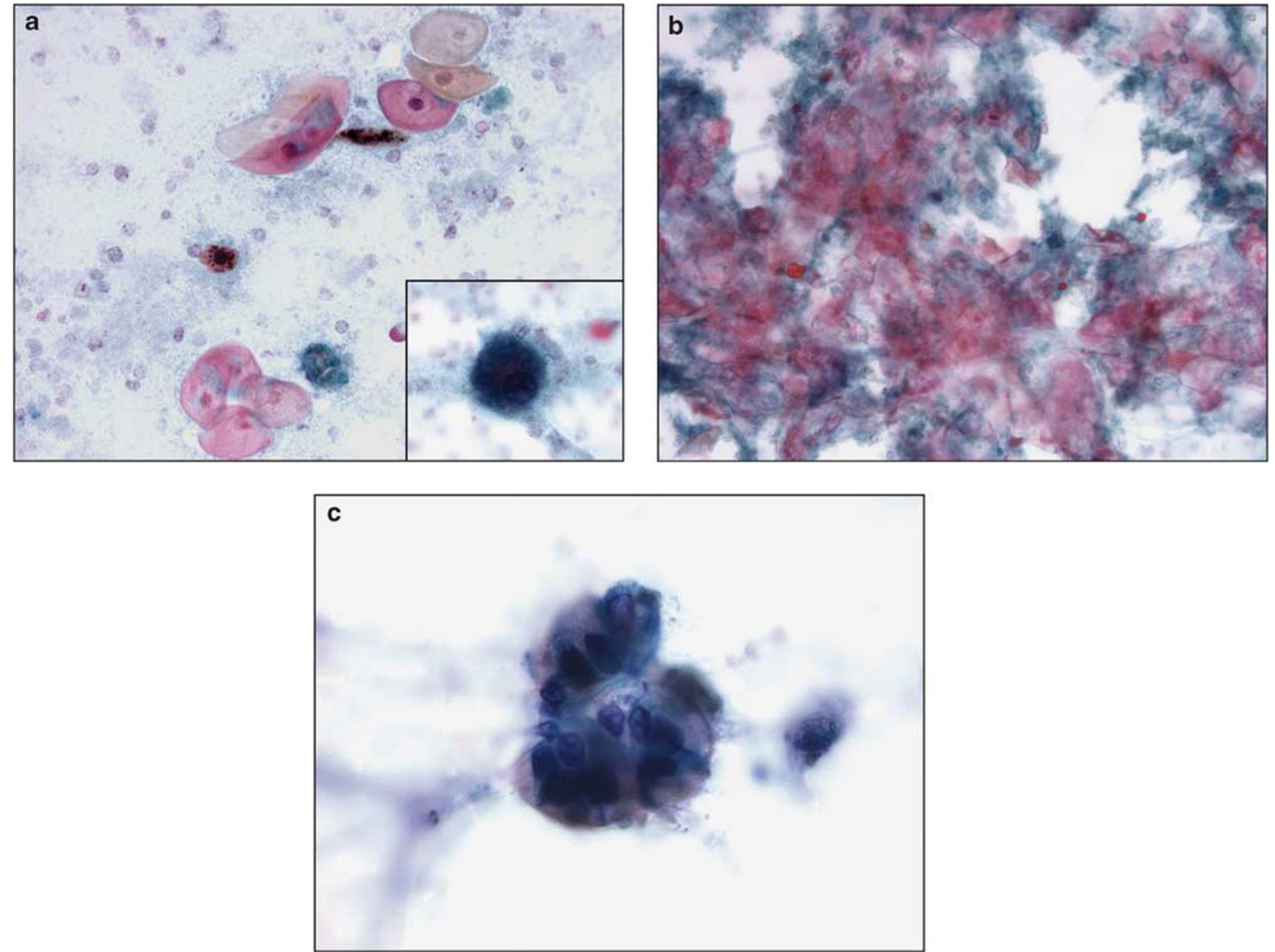

Figure 1 Cytological features of lymphoepithelial cysts. Characteristic features include (a) mature squamous cells (some with keratohyaline granules), macrophages (inset) and (b) anucleate squamous cells with keratinous debris (Papanicolaou stains). (c) This cell cluster is an example of the atypical glandular cells that can be encountered by these cyst aspirates (Papanicolaou stain); it is not known whether these glandular cells represent the mucous cells that can be present within the squamous lining of lymphoepithelial cysts. Lymphocytes are also often seen in cytological aspirates of lymphoepithelial cysts, but they were not common finding in our study.

\section{Discussion}

The pancreatic cyst lined by squamous epithelium with surrounding lymphoid tissue was first described by Luchtrath and Schriefers in $1985,{ }^{11}$ who noted the microscopic similarity of the cyst to the branchial cleft cyst of the lateral neck. The term lymphoepithelial cyst of the pancreas was proposed by Truong et $a l^{12}$ in 1987. Lymphoepithelial cysts are uncommon benign lesions that are easily diagnosed on resection specimens. They are not, however, easily diagnosed preoperatively.

Lymphoepithelial cysts pose a diagnostic dilemma in the preoperative workup of patients with pancreatic cysts because they can mimic more common neoplastic mucinous cysts based on imaging, cytological and cyst fluid studies. Distinguishing lymphoepithelial cysts from other cysts, such as pseudocysts and mucinous cysts, can be challenging on imaging studies. Features that support a lymphoepithelial cyst include visualization of a multilocular cyst on the surface of the pancreas with decreased attenuation (low Hounsfield units) on CT, hyperintensity on T1-weighted MRI, granular hypointensity on T2-weighted MRI and internal heterogeneous hyperechogenicity on ultrasound, findings that likely reflect the lipid and keratin contents of the cysts. ${ }^{13,14}$ However, lymphoepithelial cysts can have nonspecific and even misleading imaging features. The cysts can be unilocular and not obviously located on the surface of the pancreas. In our series, almost one-half $(44 \%)$ of the cysts were unilocular and more than one-half $(56 \%)$ of the cysts were located within the pancreas. By CT, lymphoepithelial cyst can appear to have solid components (due to dense keratinous material), or appear as a hypoechoic mass with an enhancing rim. ${ }^{15,16}$ By ultrasonography, lymphoepithelial cysts can appear solid or solid and cystic. ${ }^{15,16}$ Hence, although imaging studies provide information on size, location, presence or absence of solid components, and other physical descriptions, 

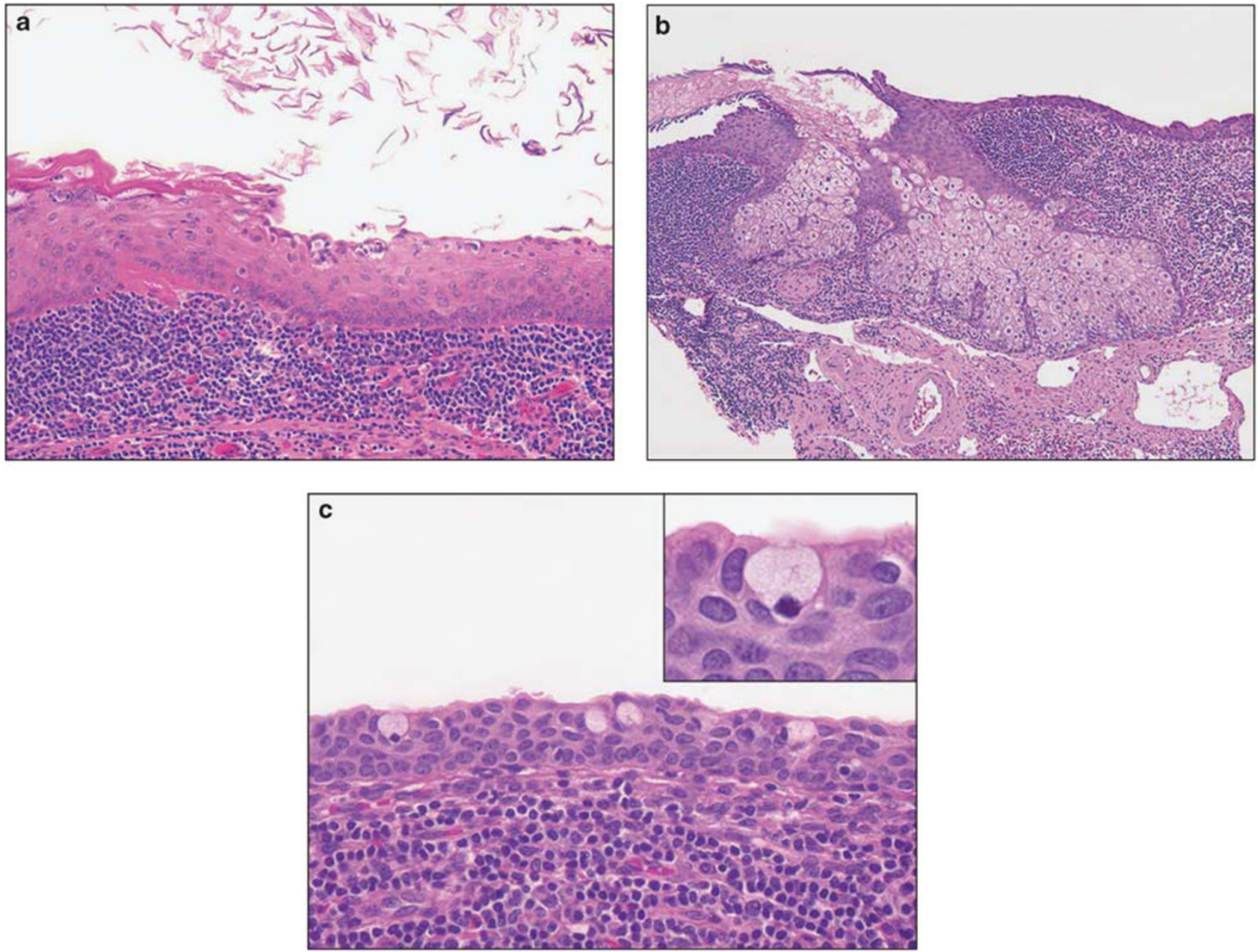

Figure 2 Histological appearance of lymphoepithelial cysts. (a) All cysts were lined by mature, stratified squamous epithelium, produced keratin (at least focally) and most (89\%) contained the characteristic dense lymphoid tissue beneath the epithelial lining. (b) Four (44\%) cysts had focal sebaceous differentiation. (c) Surface mucous cells were noted in seven (78\%) of the cysts.

they cannot rule in or out malignant or premalignant lesions.

Cytological analysis of pancreatic cyst contents obtained by FNA is an insensitive test because only small number of cells are typically present in the fluid. ${ }^{17,18}$ If squamous epithelium, keratin debris and lymphocytes are seen in the absence of worrisome features, a diagnosis of lymphoepithelial cyst can be made. In our series of lymphoepithelial cyst, only four cases (44\%) had squamous cells or squamous debris and only one case $(11 \%)$ had lymphocytes. To add to the difficulty of the cytological diagnosis, $67 \%$ of the cysts in our study had glandular cells and in five of these cases $(56 \%$ overall), atypical cytological features were present. Additionally, $33 \%$ of these cysts contained mucus or mucoid material. Overall, on the basis of the results of cytology, squamous cysts or lymphoepithelial cysts were in the differential diagnosis of $44 \%$ of our cases.

Cyst fluid analysis is another test that can assist in the preoperative diagnosis of a pancreatic cyst.
There are numerous studies in the literature that demonstrate the utility of cyst fluid analysis to distinguish neoplastic (mucinous) from nonneoplastic (nonmucinous) cysts. Currently, measurement of cyst fluid CEA appears to be the most useful discriminatory marker. ${ }^{3}$ If a cystic neoplasm is suspected on endoscopic ultrasound and there is no solid component, a cyst fluid CEA level $>200 \mathrm{ng} /$ $\mathrm{ml}$ supports the diagnosis of a mucinous neoplasm. ${ }^{3}$ Only three patients in our study had cyst fluid analysis performed, yet all three cysts had markedly elevated cyst fluid CEA levels, well above the $200 \mathrm{ng} / \mathrm{ml}$ cutoff that would support the presence of a mucinous cyst. Although our study was initiated because of this interesting observation (elevated CEA levels in lymphoepithelial cysts), this phenomenon has been reported, primarily in case reports in the literature. ${ }^{4-9}$ However, the source of the elevated CEA has not been previously systematically studied. It is interesting to note that CEA can be elevated in the cyst fluid of lymphoepithelial cysts of the head and neck, ${ }^{19,20}$ but this 

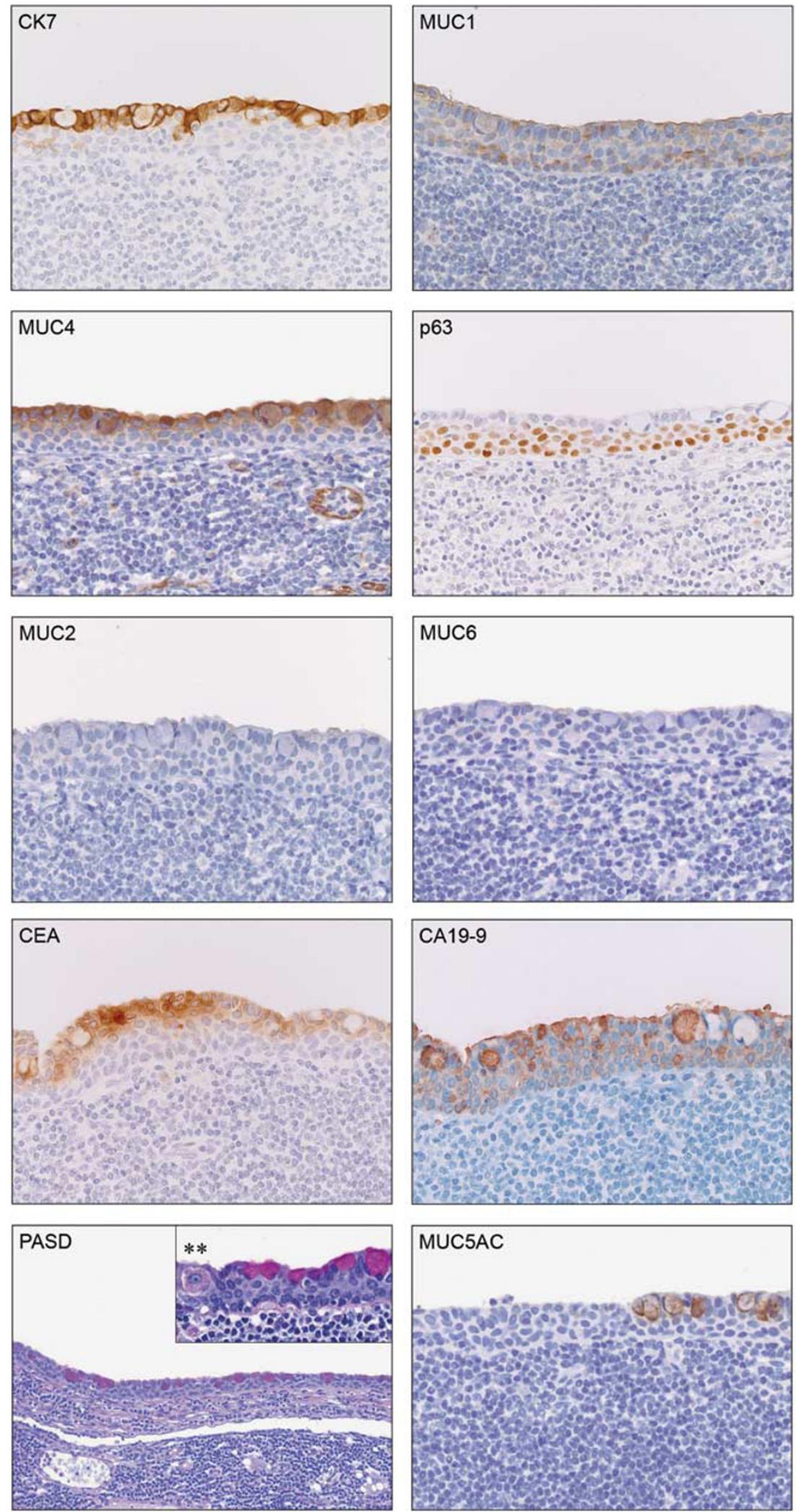

Figure 3 Typical immunohistochemical profile of lymphoepithelial cysts (these photographs were obtained from LEC4). The squamous cells were positive for CK7, MUC1 and MUC4 in all nine (100\%) cysts. All cysts (100\%) were also positive for p63 and negative for MUC2 and MUC6. Of interest, the squamous lining of all nine (100\%) cysts expressed CEA and/or CA19-9; seven (87\%) cysts expressed both CEA and CA19-9. The mucous cells were positive for PAS-D, MUC5AC, MUC4 and CK7, variably positive for CEA and CA19-9, and negative for MUC1 and MUC2 (**macrophages are weakly positive for PAS-D). 
finding does not pose the same diagnostic challenge as it does in pancreatic cysts.

By thoroughly examining the resected lymphoepithelial cysts both histologically and immunohistochemically, we made two observations that could account for the elevated CEA levels. First, we noticed that the squamous lining of lymphoepithelial cysts can contain goblet-shaped mucous cells. This observation has not been well documented. The presence of rare goblet cells was noted (but not well described) in only one pancreatic lymphoepithelial cyst in the literature. ${ }^{21}$ However, mucous cells and glandular/columnar epithelium can be a feature of lymphoepithelial cysts in the head and neck region. ${ }^{22,23}$ It is possible that these mucous cells have been overlooked in lymphoepithelial cysts of the pancreas because of their scant number and patchy distribution. Although it is possible that these MUC5AC-positive mucous cells could produce CEA, they were variably positive for CEA immunohistochemically and they were only present as a few cells scattered throughout the cyst lining. Hence, it is unlikely that these mucous cells are responsible for the marked elevation in CEA that is observed in some lymphoepithelial cysts. It is possible, though, that these cells could appear in cytological aspirates of lymphoepithelial cysts and contribute to misclassification of the cyst as a mucinous or potentially neoplastic cyst (Figure 1c).

Second, we found that the squamous cells themselves expressed both CEA and CA19-9. The squamous lining in all nine $(100 \%)$ of our cases expressed one or both these markers. The three cysts in our study that had markedly elevated cyst fluid CEA levels also had strong, patchy CEA labeling of the squamous lining, suggesting that the squamous lining is the source of the elevated cyst fluid CEA levels. CEA is a glycoprotein that is typically expressed by endodermally derived tissues and adenocarcinomas. Although the expression of CEA by squamous epithelium can occur, ${ }^{24,25}$ its expression in the squamous lining of lymphoepithelial cysts has been previously reported in only two case reports. ${ }^{7,26}$ CA19-9 is a high-molecular-weight glycoprotein that is frequently expressed in gastrointestinal adenocarcinomas, but its expression has been reported in nonneoplastic squamous mucosa and in three lymphoepithelial cysts (two of the same cysts with CEA expression). ${ }^{7,8,26,27}$ As proposed by Kaiserling et al, ${ }^{7}$ the labeling of the squamous lining of lymphoepithelial cyst by both CEA and CA19-9 suggests that the cyst lining is derived from the exocrine pancreas. This theory could also explain the presence of rare mucinous cells within the lining of the cysts. Alternatively, as sebaceous glands can be seen in lymphoepithelial cyst (44\% of our cysts had sebaceous glands), the squamous lining of lymphoepithelial cyst may be derived from ectodermal elements with aberrant expression of CEA and CA19-9.
We also studied the mucin profile of lymphoepithelial cysts. Mucins are heavily glycosylated, high-molecular-weight glycoproteins that are commonly expressed in epithelial cells. Currently, about 20 mucin $(M U C)$ genes have been identified and/or sequenced. ${ }^{28}$ Their expression is relatively specific to the types of cells or tissue. For example, MUC2 is a goblet cell mucin predominantly expressed in the intestine. ${ }^{29}$ Normal adult pancreas expresses MUC1 and MUC6, but not MUC2 and MUC5AC. MUC1 is expressed in the intercalated ductal cells $^{30}$ while MUC6 is exhibited in centroacinar cells. ${ }^{31}$ MUC4 is absent or minimally expressed in the normal pancreas. ${ }^{32}$ Interestingly, mucins are differentially expressed in mucinous cysts of the pancreas; MUC5AC is consistently expressed in the epithelial lining of pancreatic mucinous cysts; MUC2 is expressed in intestinal-type epithelial lining; and both MUC1 and MUC6 are expressed in pancreaticobiliary and oncocytic epithelial lining. ${ }^{33,34}$

The mucin expression profile of lymphoepithelial cysts has not been described previously in the literature. In our study, MUC1 and MUC4 were positive in all cysts and MUC2 and MUC6 were negative in all cysts. MUC5AC was at least focally expressed in $78 \%$ of the cysts (scattered mucous cells were positive, but the squamous epithelium was negative); thus its usefulness in ruling in or out a lymphoepithelial cyst is limited. However, the pattern of expression of mucin proteins in lymphoepithelial cysts provides insight into the pathogenesis of these cysts.

As MUC1 and MUC4 are expressed in the normal stratified epithelium, ${ }^{32,35}$ pancreatic squamous metaplasia $^{36}$ and in squamoid cysts of the pancreas, ${ }^{37}$ the presence of MUC1 and MUC4 in our study suggests that lymphoepithelial cysts may originate from the pancreatic duct with squamous metaplasia and cystic formation, or alternatively, from epithelial remnants in peripancreatic lymph nodes. ${ }^{2}$ The scattered mucous cells could represent remnant ductal epithelial cells. Interestingly, there may be an additional component of transitional metaplasia. The overall immunohistochemical profile of the squamous lining of lymphoepithelial cysts $(\mathrm{CK} 7+$, p63 +, MUC1 +, MUC4 +, MUC2-, MUC5AC- and MUC6-) is identical to that seen in normal urothelium. ${ }^{38}$ Regardless of what specific pathogenic mechanism is involved in creating lymphoepithelial cysts, these cysts have a mixed squamous-transitional-ductal phenotype that results in the expression of CEA and CA19-9.

Lymphoepithelial cysts of the pancreas have clinical, radiographic and cytological features that can lead to the misdiagnosis of these lesions preoperatively. Even though these cysts are lined by squamous epithelium, our series of resected lymphoepithelial cysts revealed that many (78\%) of these lesions contained at least focal mucous cells (which could appear as atypical cells on cytological 
analysis) and that all (100\%) demonstrated expression of CEA and/or CA19-9 on the surface of the squamous epithelium (which could account for the elevated cyst fluid CEA levels). The cysts in our study were resected because of size $\geq 3 \mathrm{~cm}(89 \%)$, symptoms (44\%) and/or elevated cyst fluid CEA levels (33\%), all features concerning for neoplastic mucinous cysts. Although a cyst fluid CEA level $>200 \mathrm{ng} / \mathrm{ml}$ generally supports the diagnosis of a mucinous neoplasm, such as a mucinous cystic neoplasm or intraductal papillary mucinous neoplasm, this study emphasizes the need for clinicians and pathologists to recognize that lymphoepithelial cysts can mimic neoplastic mucinous cysts clinically, radiographically and on cyst fluid CEA analysis.

\section{Disclosure/conflict of interest}

The authors declare no conflict of interest.

\section{References}

1 Basturk O, Coban I, Adsay NV. Pancreatic cysts: pathologic classification, differential diagnosis, and clinical implications. Arch Pathol Lab Med 2009; 133:423-438.

2 Adsay NV, Hasteh F, Cheng JD, et al. Lymphoepithelial cysts of the pancreas: a report of 12 cases and a review of the literature. Mod Pathol 2002;15:492-501.

3 Vignesh S, Brugge WR. Endoscopic diagnosis and treatment of pancreatic cysts. J Clin Gastroenterol 2008;42:493-506.

4 Centeno BA, Stockwell JW, Lewandrowski KB. Cyst fluid cytology and chemical features in a case of lymphoepithelial cyst of the pancreas: a rare and difficult preoperative diagnosis. Diagn Cytopathol 1999;21: 328-330.

5 Chan SP, Hatton CW, Falk GL. Lymphoepithelial cyst of the pancreas: serum markers do not help. HPB Surg 1998;11:121-124.

6 De Lorenzi D, Candinas D, Flury R, et al. [Lymphoepithelial cyst of the pancreas]. Helv Chir Acta 1993;60:131-135.

7 Kaiserling E, Seitz KH, Rettenmaier G, et al. Lymphoepithelial cyst of the pancreas. Clinical, morphological, and immunohistochemical findings. Zentralbl Pathol 1991;137:431-438.

8 Tsuchiya Y, Suzuki S, Sakaguchi T, et al. Lymphoepithelial cyst of the pancreas: report of a case. Surg Today 2000;30:856-860.

9 Yamaguchi T, Takahashi H, Kagawa R, et al. Lymphoepithelial cyst of the pancreas associated with elevated CA 19-9 levels. J Hepatobiliary Pancreat Surg 2008;15: 652-654.

10 Kuan SF, Montag AG, Hart J, et al. Differential expression of mucin genes in mammary and extramammary Paget's disease. Am J Surg Pathol 2001;25:1469-1477.

11 Luchtrath H, Schriefers KH. [A pancreatic cyst with features of a so-called branchiogenic cyst]. Pathologe 1985;6:217-219.

12 Truong LD, Rangdaeng S, Jordan Jr PH. Lymphoepithelial cyst of the pancreas. Am J Surg Pathol 1987;11:899-903.
13 Fukukura $\mathrm{Y}$, Inoue $\mathrm{H}$, Miyazono $\mathrm{N}$, et al. Lymphoepithelial cysts of the pancreas: demonstration of lipid component using CT and MRI. J Comput Assist Tomogr 1998;22:311-313.

14 Shinmura R, Gabata T, Matsui O. Lymphoepithelial cyst of the pancreas: case report with special reference to imaging-pathologic correlation. Abdom Imaging 2006;31:106-109.

15 Capitanich P, Iovaldi ML, Medrano M, et al. Lymphoepithelial cysts of the pancreas: case report and review of the literature. J Gastrointest Surg 2004;8:342-345.

16 Koga H, Takayasu K, Mukai K, et al. CT of lymphoepithelial cysts of the pancreas. J Comput Assist Tomogr 1995;19:221-224.

17 Brugge WR, Lewandrowski K, Lee-Lewandrowski E, et al. Diagnosis of pancreatic cystic neoplasms: a report of the cooperative pancreatic cyst study. Gastroenterology 2004;126:1330-1336.

18 van der Waaij LA, van Dullemen HM, Porte RJ. Cyst fluid analysis in the differential diagnosis of pancreatic cystic lesions: a pooled analysis. Gastrointest Endosc 2005;62:383-389.

19 Hirota J, Maeda Y, Ueta E, et al. Immunohistochemical and histologic study of cervical lymphoepithelial cysts. J Oral Pathol Med 1989;18:202-205.

20 Yamamoto $M$, Tsuji M, Yamada K, et al. Cyst fluid levels of carcinoembryonic antigen, carbohydrate antigen 19-9, squamous cell carcinoma antigen, and amylase in thyroglossal duct and branchial cleft cysts. Surg Today 2001;31:477-481.

21 Goodman P, Kumar D, Balachandran S. Lymphoepithelial cyst of the pancreas. Abdom Imaging 1994;19: 157-159.

22 Pieterse AS, Seymour AE. Parotid cysts. An analysis of 16 cases and suggested classification. Pathology 1981;13:225-234.

23 Eveson JW, Nagao T. Diseases of the salivary gland. In: Barnes L (ed). Surgical Pathology of the Head and Neck, Vol. 3rd edn. Informa Healthcare USA, Inc.: New York, 2009, pp 481-482.

24 Chen SW, Liang JA, Hung YC, et al. Clinical implications of elevated pretreatment carcinoembryonic antigen in patients with advanced squamous cell carcinoma of the uterine cervix. Tumour Biol 2008;29:255-261.

25 Yanagawa T, Hayashi Y, Nishida T, et al. Immunohistochemical demonstration of carcinoembryonic antigen (CEA) on tissue sections from squamous cell head and neck cancer and plasma CEA levels of the patients. Int J Oral Maxillofac Surg 1986;15:296-306.

26 Tateyama H, Tada T, Murase T, et al. Lymphoepithelial cyst and epidermoid cyst of the accessory spleen in the pancreas. Mod Pathol 1998;11:1171-1177.

27 Wiest I, Schulze S, Kuhn C, et al. Expression of the carbohydrate tumour marker SLeX, SLeA (CA19-9), LeY and Thomsen-Friedenreich (TF) antigen on normal squamous epithelial tissue of the penis and vagina. Anticancer Res 2007;27:1981-1988.

28 Byrd JC, Bresalier RS. Mucins and mucin binding proteins in colorectal cancer. Cancer Metastasis Rev 2004;23:77-99.

29 Allen A, Hutton DA, Pearson JP. The MUC2 gene product: a human intestinal mucin. Int J Biochem Cell Biol 1998;30:797-801.

30 Wada R, Ogawa K, Yamaguchi T, et al. Intercalated duct cell is starting point in development of pancreatic ductal carcinoma? J Carcinog 2005;4:9. 
31 Bartman AE, Buisine MP, Aubert JP, et al. The MUC6 secretory mucin gene is expressed in a wide variety of epithelial tissues. J Pathol 1998;186:398-405.

32 Chaturvedi P, Singh AP, Batra SK. Structure, evolution, and biology of the MUC4 mucin. FASEB J 2008;22:966-981.

33 Basturk O, Khayyata S, Klimstra DS, et al. Preferential expression of MUC6 in oncocytic and pancreatobiliary types of intraductal papillary neoplasms highlights a pyloropancreatic pathway, distinct from the intestinal pathway, in pancreatic carcinogenesis. Am J Surg Pathol 2010;34:364-370.

34 Furukawa T, Kloppel G, Volkan Adsay N, et al. Classification of types of intraductal papillary-mucinous neoplasm of the pancreas: a consensus study. Virchows Arch 2005;447:794-799.
35 Guillem P, Billeret V, Buisine MP, et al. Mucin gene expression and cell differentiation in human normal, premalignant and malignant esophagus. Int J Cancer 2000;88:856-861.

36 Swartz MJ, Batra SK, Varshney GC, et al. MUC4 expression increases progressively in pancreatic intraepithelial neoplasia. Am J Clin Pathol 2002;117:791-796.

37 Othman M, Basturk O, Groisman G, et al. Squamoid cyst of pancreatic ducts: a distinct type of cystic lesion in the pancreas. Am J Surg Pathol 2007;31: 291-297.

38 N'Dow J, Pearson JP, Bennett MK, et al. Mucin gene expression in human urothelium and in intestinal segments transposed into the urinary tract. J Urol 2000;164:1398-1404.

Supplementary Information accompanies the paper on Modern Pathology website (http://www.nature.com/ modpathol) 